Moreover, when we remember what unexplainable cases of inheritance occur, such as special movements during sleep, we must admit that even the tendency in a snake to incubate its eggs may also be transmitted, the more so as we have an indisputable inheritance of the same nature daily shown $u_{3}$ in the case of birds, for the tendency of the parents to incubate their young is in all cases inherited by the offspring.

686 Lexington Avenue, New York. Clement Fezandie.

\section{Another Ancient Argillite Quarry Near Trenton,}

ON the left bank of Neshaming " Creek," Bucks County, Pennsylvania, about three-fourths of a mile above the mouth of Labaska or Mill Creek, I discovered at the base of the cliffs of metamorphosed slate that there overhang the stream, on June 23, another ancient work-shop where blocks of argillite, lying in situ, have been chipped into "turtle-backs."

A layer of chips, hammer-stones, and the now familiar rude leaf-shaped forms is laid bare for several hundred yards where the stream has worn away the margin. The blocks of workable stone in various instances show peckings upon their sides, as do similar specimens at Point Pleasant, inferably made by the ancient workmen to split them with the grain.

No search has yet been made for diggings and refuse-heaps higher up the slope, nor has excavation been made into the exposed layers: but thus far the story of the workings on Gaddis' Run, near Point Pleasant (Bucks County, Pennsylrania), discovered on May 22, seems to be repeated, though on a smaller scale. There we were twenty-five miles from Trenton; here we are but fifteen.

H. C. MERCER.

\section{Do Nestlings Drink.}

This question suggested itself to my mind very lately, when I observed the following, and to me, entirely new fact:

A piazza-roof, on which my windows open, is provided with a shallow gutter, in which there is a considerable accumulation of the winged seeds from a neigbboring tree. These were standing in shaliow water, left there by the recent rains.

I obserred a robin alight on the roof, and noticed that she picked from the gutter a bunch of those seeds, which she held in her bill while she seemed to be preparing to fly awas.

Presently, apparently dissatisfied with what she had picked up, she dropped the seeds, and moving to a place where they were lying in a thicker bed, she gathered a much larger mass of them, about as many as her bill would hold together. After gathering them and satisfging herself that she had enough, she deliberately dipped the mass into the water and flew away with it to a distant tree. Perhaps some of your readers may suggest a truer explanation; but to me she seemed to be carrying a supply of water to her brood in what was no inadequate substitute for a sponge.

Geneva, N. Y., June 28

Francis Philip Nash.

\section{BOOK-REVIEWS.}

Logarithmic Tables. By Professor G. W. Jones. Ames, Iowa, the Author.

THE title of this book does not exactly describe its contents. The strictly logarithmic tables are only about one-half of those given. The arrangement of the tables, of which there are eighteen, has been made to meet the wants of those who desire to have, in a handy form, tables to be used in computations covering a wide range. Table $I$. is a four-place, of numbers from 1 to 1,000 , followed by one of the same accuracy giving the six principal trigonometric functions, and of the lengths of arcs in radians. The first five degrees of the quadrant are given to each five minutes, the following to each ten minutes, with differences for single minutes. A table giving the squares, cubes, square-roots, cube-roots, and reciprocals of the numbers $1,2,3,99$ is also given. Table III. is a six-place table of numbers, the side numbering being carried to only three figures instead of four, as is usual in
CALENDAR OF SOCIETIES.

Agassiz Scientific Society, Corvallis, Ore. June 14.-Dr. Pernot, Aphasia.

Reading Matter Notices.

Ripans Tabules cure hives.

Ripans Tabules cure dyspepsia.

RACK NUMBERS and complete sets of leading Mag. azines. Rates lo

\section{RESTORE YOUR EYESIGHT \\ Cataracts, scars or films can be absorbed and paralyzed nerves restored, with out the knife or risk. Diseased eyes or lids can be cured by
our home treatment. "We prove it." Hun-
dreds convinced. Our illustrated pamphlet, dreds convinced. Our illustrated pamphlet,
'Home Treatment for Eyes," free. Don't miss it. Everybody wants it. “ THE EYE," Glens Falls, N.Y.}

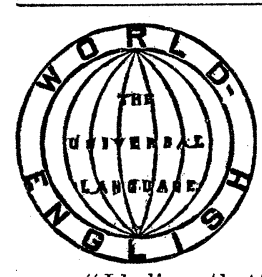

WORLD-ENGLLSH. 25 Cents.

HANDBOOK OF WORLD-ENGLISH. 25 Cents.

Ex - President Andrew D. says: "I believe thatthe highest interests of Christian civilization and of humanity would be served by its adoption."

"So set down, our tongue is the best for the world to unite upon."-Brooklyn Eagle.

"The idea of Mr. Bell has much to recommend it and the presentation is charmingly clear." - Ameri. can, Phila.

"The result is a language which cannot fail to "eet with acceptance." - Boston Traveller.

"Worla. English deserves the careful consideration nguage Notes.

Sent, postpaid, on receipt of price.

N. D. C. HODGES, 874 Broadway, N. Y.
THE MODERN MALADY ; or, Suf- Pennsylvania Bedford Springss Mineral Water ferers from 'Nerves.'

An introduction to public consideration, from a non-medical point of view, of a condition of ill-health which is increasingly prevalent in all ranks of society. In the first part of this work the author dwells on the errors in our mode of treating Neurasthenia, consequent on the wide ignorance of the subject which still prevails; in the second part, attention is drawn to the principal causes of the malady. The allegory forming the Introduction to Part I. gives a brief history of nervous exhaustion and the modes of treatment which have at various times been thought suitable to this most painful and trying disease.

By CYRIL BENNETT. $12^{\circ}, 184$ pp., $\$ 1.50$.

N. D. C. HODGES, 874 BROADWAY, NEW' YORK.

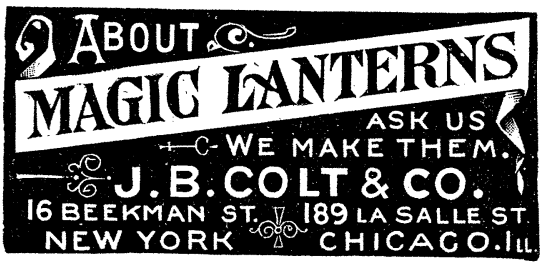

For Liver, Kidney and Bladder Troubles. For Gravel, Gall Stones, Jaundice. For Dyspepsia, Rheumatism and Gout. For Dropsy, Bright's Disease, Diabetes. For Hemorrhoids, Etc.

It has been used medicinally and prescribed by hysicians for nearly one hundred years. DIRECTIONS:-Take one or two glasses about a Case One Dozen Half-Galion Bottles, $\$ 4.50$. Case Fifty Quarts (Aerated), $\$ 7.50$.

Bedford Mineral Springs Co., Bedford, Pa Philadelphia Office, 1004 Walnut St.

\section{CSTERBROOK'S} E STEEL PENS. OF SUPERIOR AND SIANDARD QUALITY.

Leading Nos.: 048, 14, 130, 135, 239, 333 For Sale by all Stationers.

the esterbrook steel PEN co. Works: Oamden, N. J. 26 John St., NewYork. MINERALS. Noww Storece.

New bepartments Minerals, our "Winter Bulletin," recently issued. Minerals, Gems, Microscopical Sections, Fine Lapidary Work.

GEO. L. ENGLISH \& CO., Mineralogists, Removed to 64 East 12th Street, New York

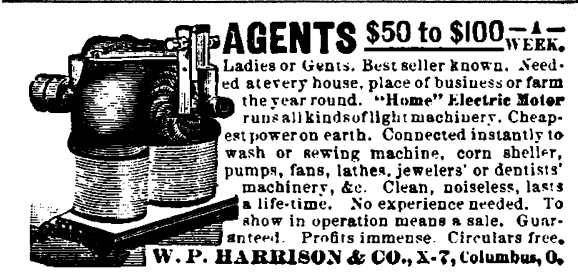


such tables. In Table IV. will be found all of the useful constants used in mathematics, chemistry, engineering, physics, and weights and measures. This table is a very complete one, containing, as it does, reference to almost every standard and constant used in the arts and science. Table V. is a reprint of the Gaussian sixplace addition-subtraction logarithms. For determining trigonometric functions, there are two tables, the four-place already mentioned, and also a six-place table. The latter is a departure from the usual method. Generally, in a six-place table, the functions are given for each ten seconds. Professor Jones has made up the table for each minute of the quadrant, the proportional part being giren for each second. The tables that follow those just explained consist of prime and composite numbers, squares, cubes, square-roots, cube-roots, reciprocals, and quarter-squares. Finally, we have Bissel's table of coefficients for interpellation, and a table containing the integral for finding the mean or probable error of a result in least squares. We judge from our examination that Professor Jones has prepared the tables with great care. $\mathrm{He}$ seems exceedingly anxious to free them of all errors, and to induce that condition of things he offers a reward for an error found in the tables. We have not critically examined the tables, but we note a slight error in the text. On the first page the reference to the pages containing Table IX. should read 118-133 instead of 114-133. We would commend these tables to the computer as being a help to have on one's desk.

G. A. H.

Pioneers of Science. By OLIVER LODGE, F. R. S., Professor of Physics in Victoria University College, Liverpool, with Portraits and Illustrations. London, Macmillan \& Co. 404 p. $8^{\circ}$. $\$ 2.50$.

IN this work, Dr. Lodge has given the general public and the student a very interesting and readable book. As he states in his preface the book had its origin in a course of lectures on the history and progress of astronomy, delivered by the author in 1887. As is often the case with books based on a course of lect- ures, it is somewhat disjointed. It is full, however, of interesting matter, and is lavishly illustrated, an unusual feature in works of this class. Its title is unfortunately misleading as the author does not attempt to cover the whole growth of scientific knowledge, but confines himself to astronomy. The book, however, is unique in the endeavor by means of plain, unaffected writing and a wealth of illustration to bring the pioneers of celestial knowledge into almost personal acquaintanceship with the reader, tracing the history of their discoveries and the dependence of one discovery upon another. It is to be commended to students of the history of science as a most useful reference book, and to the genenal reader as a book. at once entertaining and instructive.

J. E. I.

\section{AMONG THE PUBLISHERS.}

THE career of the late Sir Richard Burton, the distinguished traveller, was most adventurous and romantic. He was an encyclopædic scholar, and much more than a scholar. He knew and had seen more of dark Africa than most men, and more of Mohammedan lands than any man. His biography, by Lady Burton, will be published shortly by D. Appleton \& Co. The book will be decorated with illustrations and maps, as well as portraits. The first part of the story, it is said, will in the main be told in Sir Richard's own words.

- The weekly paper known for the last twenty-five years as The Christian Union with its first issue for July changes its title to The Outlook. It will remain unchanged in other respects, except in the line of improvement and enlargement. It will be, as before, a family paper, non-denominational in religious matters, and giving large space to the current history of our times; to literature, economics and progressive movements of all sorts, and to home life. The Rev. Dr. Lyman Abbott will remain as its editor-in-chief, with Mr. Hamilton W. Mabie as his associate, and an editorial staff of several members.

\section{Delicious Drink.}

\section{Horsford's Acid Phosphate}

with water and sugar only, makes a delicious, healthful and invigorating drink.

Allays the thirst, aids digestion, and relieves the lassitude so common in midsummer.

Dr, M. H. Henry, New York, says: "When completely tired out by prolonged wakefulness and overwork, it is of the greatest value to me. As a beverage it possesses charms beyond anything I know of in the form of medicine."

Descriptive pamphlet free.

Rumford Chemical Works, Providence, R. I. Beware of Substitutes and Imitations.

\begin{tabular}{|c|}
\hline $\begin{array}{c}\text { Exchanges. } \\
\text { [Free of charge to all, if of satisfactory character. } \\
\text { Address N. D. C. Hodges, } 874 \text { Broadway, New York.] }\end{array}$ \\
\hline $\begin{array}{l}\text { I have a fire-proof safe, weight } 1,150 \text { pounds, } \\
\text { which I will sell cheap or exchange for a gasoline } \\
\text { engine or some other things that may happen to } \\
\text { suit. The safe is nearly new, used a short time } \\
\text { only. Make offers. A. Lagerstrom, Cannon Falls, } \\
\text { Minn., Box 857. }\end{array}$ \\
\hline $\begin{array}{l}\text { For exchange.- Hudson River fossils in good con- } \\
\text { dition from the vicinity of Moore's Hill, Ind., also } \\
\text { land and fresh water shells. Desire fossils and } \\
\text { shells from other groups and localities. Address } \\
\text { Geo. C. Hubbard, Moore's Hill, Ind. }\end{array}$ \\
\hline $\begin{array}{l}\text { For sale at low price.-A fine old-fashioned photo- } \\
\text { graphic camera, rosewood box, one foot square, } \\
\text { lenses four inches diameter, made by C. C. Harri- } \\
\text { son. Plateholders, troughs, baths, etc., all in large } \\
\text { wooden ease, formerly the property of the late } \\
\text { President Moore, of ciolumbia College. This is a } \\
\text { fine example of an instrument of the best make for } \\
\text { the old wet-process methods, and valuable to any } \\
\text { institution or amateur interested in the history of } \\
\text { photography in the U. S. Address M. S. Daniel, } \\
236 \text { W. 4th St., New York. }\end{array}$ \\
\hline $\begin{array}{l}\text { I wish to exchange a collection of } 7,000 \text { shells, } \\
1001 \text { species and varieties, American and foreign, } \\
\text { land, fluviatile and marine, for a good microscope } \\
\text { and accessories. Address, with poarticulars, Dr. } \\
\text { Lorenzo G. Yates, Santa Barbara, California. }\end{array}$ \\
\hline $\begin{array}{l}\text { For exchange.-I wish to exchange Lepidoptera of } \\
\text { South Dakota and other sections, for Lepidoptera } \\
\text { of the world. Will purchase species of North Amer- } \\
\text { ica. Correspondence solicited, particularly with } \\
\text { collectors in the Rocky Mountains, Pacifie coast } \\
\text { and Hudson's Bay regions. P. C. Truman, Volga, } \\
\text { Brooking county, South Dakota. }\end{array}$ \\
\hline 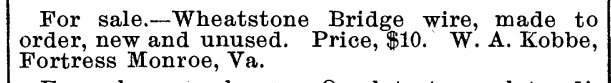 \\
\hline $\begin{array}{l}\text { For sale or exchange.-One latest complete edi- } \\
\text { tion of Watt's Dictionary of Chemistry, in fair con- } \\
\text { dition, one thirty volume edition (9th) of Allen's } \\
\text { Encyclopædia Britannica, almost new. Will sell } \\
\text { cheap for cash or will exchange for physical or } \\
\text { ehemical apparatus. Address Prof. W. S. Leaven- } \\
\text { worth, Ripon College, Ripon, Wis. }\end{array}$ \\
\hline $\begin{array}{l}\text { Exchange.-One celestial, one terrestrial globe, } \\
\text { one lunatettis and charts, celestial maps, diagrams } \\
\text { and ephemeris from } 1830 \text { to } 1893 \text {, astronomical } \\
\text { works, all in good condition. Will sell cheap or ex- } \\
\text { change. Make offer. C. H. Van Dorn, 79 Nassau } \\
\text { St., New York. }\end{array}$ \\
\hline
\end{tabular}

\section{Exchanges.}

I have a fire-proof safe, weight 1,150 pounds, engine or some other things that may happen to The safe is nearly new, used a short tim Minn., Box $85 \%$.

For exchange.-Hudson River fossils in good conland and fresh water shells. Desire fossils and shells from other groups and localt

For ale at low price $A$ fine raphic camera, rosewood box, one foot square, son. Plateholders, troughs, baths, etc., all in large President Moore, of ciolumbia College. This is a the example wet an instrument of the best make for institution or amateur interested in the history of hotography in the U. S.

I wish to exchange a collection of 7,000 shells, 1001 species and varieties, American and foreign, and accessories Address with particulars, Dr. Lorenzo G. Yates, Santa Barbara, California.

For exchange.-I wish to exchange Lepidoptera of
south Dakota and other sections, for Lepidoptera South Dakota and other sections, for Lepitoptera
of the world. Will purchase species of North America. Correspondence solicited, particularly with and Hudson's Bay regions. P. C. Truman, Volga,

order new and unused. Price 110 . W. A. Kobbe cheap for cash or will exchange for physical or (hemical apparatus. Address Prof.

Exchange.-One celestial, one terrestrial globe, and ephemeris from 1830 to 1893 , astronomical change. Make
Wants.

ARADUATE of an American Polytechnic instiseeks a position to teach chemistry in a college seeks a position to teach chemistry in a college or
similar institution. Five years' experience in teaching chemistry, Address Chemist, 757 Cary St. Brockton, Mass.

$\mathrm{A}^{\mathrm{N}}$ experienced teacher in general biology wishes $A$ a position in a first-class college or university. Three years in post-graduate study. Extensive experience. Strong indorsements. Address E. W.
Doran, Ph.D., 1327 G St., N. W., Washington, D. C.

THREE teachers wanted for a male and female Teminary in central New York. Typewriting, stamp with and for particulars. Box 701 , Hempstead, L. I.

AOOLOGICAL collector and taxidermist of ten years' experience in the field is now open to engagement, for either field or laboratory work. References furnished. Address Taxidermist, Box 75, White Sulphur Springs, West Va.

$W_{\text {Analysis, } 4 \text { vols. Vols. I. and II. particularly }}^{\text {ANTED. A set of }}$ Analysis, 4 vols. Vols. I. and II. particularly present and in place. Address Charles Platt, 34
Lewis Block, Buffalo.

$W^{\text {ANTED, as principal of a flourishing technical }}$ W school, a gentleman of education and experi chanical and common school instruction familiarity with some technical branch desirable. Address, giving age qualifications, etc., J. B. Bloom ingdale, Fifty-ninth street and Third avenue, N. Y $W^{\text {ANTED }- \text { - A young man as assistant in our }}$ $W$ microscopical department. Queen \& Co.,
Philadelphia.

$T^{\mathrm{HE}}$ undersigned desires specimens of North American Gallinae in the flesh for the study of their pterylosis. These species are especially desired: Colinus ridgwayi, cyrtonyx montezumae deudragapus franklini, lagopus welchi, tympanuchus cupido and pedioecetes phasianellus. Any persons having alcoholic specimens which they are willing
to loan or who can obtain specimens of any of the above are requested to communicate with of th Lyman Clark, 3922 Fifth Avenue, Pittsburgh, Pa. 